\title{
MOTOR ABILITIES, MOVEMENT SKILLS AND THEIR RELATIONSHIP BEFORE AND AFTER EIGHT WEEKS OF MARTIAL ARTS TRAINING IN PEOPLE WITH INTELLECTUAL DISABILITY
}

\author{
Samo Masleša, Mateja Videmšek*, Damir Karpljuk*
}

Independent researcher, Ljubljana, Slovenia

* Faculty of Sport, University of Ljubljana, Ljubljana, Slovenia

Submitted in May, 2010

BACKGROUND: A part of the population of people with intellectual disability is historically inclined to obesity and in a poorer health condition. That is the reason why sport should play an important role in their lives. Designing scientifically and professionally valid training programmes, consisting of the necessary methodology and didactical instructions for sport engagement of people with intellectual disability, is not only a challenge but has become a necessity for the near future.

OBJECTIVE: The aim of the study was to establish a correlation between selected motor abilities and motor skills of martial arts as well as how and to what extent a group of people with intellectual disability (ID) who regularly practice Gan (inclusive) judo can achieve progress in their martial arts skills (judo, karate, boxing and fencing) after an eight week training programme. We were also interested in whether there were any changes in selected motor abilities.

METHODS: Measurement of motor abilities and selected martial art skills was conducted twice - in March 2008, one week before the eight week training started, and in May 2008, one week after it had been completed. The training programme lasted for two months, with two sessions per week. The sample of subjects comprised 5 women and 18 men aged between 16 and 36, with mild and moderate intellectual disability. The study was conducted using 8 tests to assess motor abilities and 9 tests to assess martial art skills.

RESULTS: The results of a t-test for dependent samples showed statistically significant differences between the initial and final measurements in seven tests of motor abilities and eight tests of martial arts skills, while a significant correlation was found between the overall average score of martial arts and results of seven motor ability tests in the initial and five in the final measurement.

CONCLUSSIONS: After the training process positive changes in motor abilities and motor skills of Gan judokas had been noted. The effects of the training program should be verified in future studies. It is worth reiterating that by improving motor abilities and expanding the boundaries of skills, people with intellectual disability enhance their quality of life. Attention in the future and thus contributes to a higher quality of intellectually disabled people's engagement in sport as well as in life.

Keywords: Motor learning, retention, correlation.

\section{INTRODUCTION}

Sport influences the development of one's personality in a comprehensive way by boosting self-confidence, promoting values such as respect for other people and obeying of rules (in both sport and life), developing diligence, and helping one to cope with challenges, accept defeats and constructively overcome any difficulties, which is why it is good training for life.

Sport also plays an important role in the life of people with intellectual disability (ID). Since a part of the population of people with ID is historically inclined to obesity and in a poorer health condition - both as a consequence of insufficient physical activity and genetic differences (Frey \& Chow, 2006; Yamaki, 2005; Temple, Frey, \& Stanish, 2006) - it had been considered until re- cently that people with ID, on the periphery of society, should be resting and leading a "passive" life to prevent something worse happening to them (Goffman, 1991; Burnik \& Brod, 2006). Consequently, motor deficiency, which is reflected in the information and energy components of movement (Filipčič, 2003; Frey \& Chow, 2006; Temple et al., 2006), further increases with adolescence (Wall, 2004, in Zhang, 2005).

With the development of sport science and its intertwining with other scientific fields, including sport for people with ID, these stereotypes and prejudices have been proven utterly incorrect. Though we know perfectly well today that sport and movement play an important role in the life of this population, also in terms of socialisation, destigmatisation and normalisation of life (Dadič, 2000; Ninot, Bilard, \& Delignieres, 2005), only 
a good third of people with ID are physically active to the extent corresponding to the standard medical recommendations (Temple et al., 2006).

Individuals with ID experience unique external barriers to physical activity dictated by support, such as overprotection by caregivers, agency structures and lack of opportunities (Stanish, Temple, \& Frey, 2006)

To design scientifically and professionally valid training programmes, consisting of the necessary methodology and didactical instructions for sport engagement of people with ID, is not only a challenge but has become a necessity for the near future.

Impact of physical activity programmes on motor abilities and motor skills of people with intellectual disability

According to the findings of experts in the fields of social work, special education and sport science, concrete training programmes - with specific limitations - can be designed for people with ID (Dadič, 2000; Masleša, Videmšek, \& Karpljuk, 2008; Masleša, Videmšek, \& Karpljuk 2009).

It is understood that consistently implemented training programmes lead to corresponding progress most of the time (Karpljuk, 1999; Choi, Meeuwsen, \& Stenwall, 1999; Gleser et al., 1992; Schmidt \& Lee, 1999). It is important that people with ID are considered on the basis of an individualised approach which relies on their medical, motor and mental characteristics, even if they are already members of more or less homogeneous groups.

In martial arts, long term observation and a good knowledge of the peculiarities and tests should provide a sufficient basis for dividing people with ID into relatively homogeneous groups (Dadič, 2000; Masleša et al., 2009). Practice has shown that detailed planning of the training process is more often than not unfeasible. ID people's motivation changes frequently and unpredictably, and many times such changes prevent them from accomplishing the plan of activities and achieving the set goals (Eichstaedt \& Lavary, 1992; Masleša et al., 2009). Therefore, the first task is strengthening the exercisers' motivation and preparing a maximally flexible plan of activities, while keeping the goals of the training in sight at all times.

Progress should be determined by comparing the initial and final measurements in a specific training period. While comparing the initial and final measurements in tests with numerical results (time, length, height, body weight, etc.) can be a relatively simple task, tests measuring progress in terms of various sports knowledge and skills can present a real challenge (Majerič, 2004).

Learning, retention and transfer of motor abilities and skills are processes which have received a lot of research attention. No effort has been spared to understand them. Schmidt and Lee (1999) defined learning as a series of processes which are connected either to exercise or experience and lead to relatively permanent changes in the understanding of a specific movement. To establish these changes, standards of knowledge and skills must be set and description sheets prepared as well as mistakes, evaluation criteria and a final scoring method defined (Majerič, 2004; Masleša et al., 2009).

The teacher should carefully select the most efficient method of practice in relation to the type of motor skill and to the participants' mental level (Matsouka, Trigonis, Simakis, Chavenetidis, \& Kioumomourjoglou, 2010). The limits defined in the evaluation sheets must be adjusted to the population which is to be tested and the gaps between the grades should be less exacting than those intended for the "average" population. The tests must be progress-sensitive, thus requiring from the evaluator a detailed knowledge of the correct technique and the tested persons' morphological limitations which stem from their medical condition. Last but not least, it is crucial that the evaluator applies the same evaluation criteria for all tested persons (Masleša et al., 2009; Majerič, 2004).

As cognitive abilities, motor abilities and skills correlate (Hayes \& Taplin, 1993), motor learning by people with ID is much slower than that in the "average" population (Francis \& Rarick, 1960; Rarick \& Dobbins, 1972, 1976; Jovanović, Bala, Banić, et al., 1983; Yun \& Shapiro, 2004). Performance of persons with ID shows dramatic improvement with practice even in tasks that are very simple, and seem to offer little room for improvement (Latash, 2007). With appropriate training, individuals with Down syndrome can achieve similar levels of motor performance to that described in the literature for individuals who are neurologically normal, but with different dynamics of motor learning (Almeide, Corcos, \& Latas 1994). For example, when a person without ID is instructed to perform a very quick and accurate movement of the elbow to a target, it takes only a few familiarization trials to reach a performance level that remains virtually unchanged in the course of massive practice (Jaric et al., 1993). The improvement is of the order of only $10 \%$. In contrast, persons ID show relatively poor performance in the familirization state and can achieve $100 \%$ improvement after two weeks of intensive training or 1,100 movements (Almeide et al, 1994), special importance should be given also to the distribution of the practice (Matsouka et al., 2010) .

From among possible movements the control methods most efficient is no doubt the feedforward mode, which can be adopted only in predictable environments (Petrynski, 2010). The coach must repeatedly demonstrate and explain the elements, even with basic and simple motor structures. The exercisers should be motivated throughout the exercise even through feedback (Dadič, 2000). For the stability of the motor learning it is also really important the frequency of feedback, that should not be given to often, because it can inter- 
fere with learning and retention of tasks for individuals with ID (Rice \& Hernandez, 2006). The focus of attention has to be directed at the movement effects (external focus) (Wulf, Shea, \& Lewthwaite, 2010).

Motor learning in homogeneous groups advances relatively faster than in heterogeneous groups. The coach's work is much easier and smoother and the motivation is stronger. Progress in motor abilities is faster and, if the exercisers within a group do not differ substantially, the final result is better. This type of training organisation enables a more accurate definition of goals and work methods (Masleša et al., 2009). However, in reality, the groups are composed by individuals of different rates of intellectual disability. To make the process more effective, individualized and safer for the participants, it is important to make appropriate coupling within the groups and the supervision of several coaches at the same time. In the Slovenian town Koper, there are normally 5 coaches for 10 participants (Masleša et al., 2009).

Until recently, not many researchers have delved into the relationship between motor abilities and motor skill performance. Magill's stated that motor abilities, refer to underlining capacities that contribute to performance of movement skills (Magill, 2011). The confirmation could be found in the spatial similarity of cognitive and motor processes that use the same brain structures (Ridler et al., 2006). Those finding prompted many researchers to highlight the relationship between motor abilities and motor skills.

While in the average population significant correlation was already established between the tests of drumming with the hands and the standing broad jump with the overall average score of motor skills in physical education (Majerič, 2004), the basic motor abilities and the results of basketball skills (Hadžikadunić, Hadžikadunić, Pavlović, \& Jakšić, 2009) and water polo skills (Aleksandrović, Naumovski, Radovanović, Georgiev, \& Popovski, 2007), we still do not known a lot about the relationship between motor abilities and performance of specific motor skills in people with ID.

Masleša et al. (2009) claim that blocks, blows with the feet(kicks) and fencing lunges are relatively demanding movements as their execution is influenced not only by technique but other factors as well. In their article they hypothesize that to strike with the foot one needs good balance, co-ordination of movement and strength in the lower extremities. The execution of a block depends on the co-ordination of both arms (arm movement co-ordination) and flexibility of the shoulder girdle, whereas the fencing lunge is not determined only by co-ordination of the body as a whole but also by flexibility and endurance in the lower extremities, but they did not make accurate analyses to establish the relationship between motor abilities and martial art skills. They argued that training of martial arts for people with
ID can positively affect the development of motor abilities, while acquiring martial arts skills is a useful tool for enhancing the safety and quality of life and that adequate levels of motor skills may contribute positively to activities of daily living in people with ID (Masleša et al., 2009). Tsimaras and Fotiadou (2004) stated that motor abilities enables people with Down syndrome to be more sociable and capable of integration into the working place.

The study aimed to demonstrate the differences between initial and final measurements in terms of motor abilities and selected martial arts skills, which were observed after an eight week planned training process, as well as establish the relationship between them.

\section{METHODS}

\section{Participants}

The study involved 23 individuals with mild and moderate intellectual disability ( 5 women and 18 men), aged between 16 and 36 years $(M=26.7, S D=5.4)$, who had been practicing Gan (inclusive) judo from 2 to 10 years $(M=6.4, S D=2.1)$ in two Slovenian towns (Koper and Ljubljana). The average weight of the participants was $78.4 \mathrm{~kg}(\mathrm{SD}=18.3)$, the average BMI was $27.0(\mathrm{SD}=4.7)$.

\section{Research design}

According to the restricted number of participants, the uniqueness of the population of people with ID who practice Gan judo in Slovenia, and the comparable recent literature for the population with ID (Duronjić \& Válková, 2010; Finn \& Válková, 2007; Fragala-Pinkham, Haley, Rabin, \& Kharasch, 2005; Oriel, George, \& Blatt, 2008), the authors decided to analyze the differences between the initial and the final measurement, without including a control group, understanding the limitation of the study, presented by the impossibility to assess the effects of the training program.

Motor skills from different martial arts were chosen because of two main reasons - (1) to establish the motor performance (motor abilities and motor skills) of people with ID who practice martial arts and (2) to access the information about motor learning of various (different) kind of skills (skills performed on the ground and in the standing position, punches, blocks, throws, falls, symmetric and asymmetric skills, unilateral and bilateral skills), that could be an useful tool in increasing the independence, safety and the quality of life of people with ID.

Measurement of motor abilities and selected martial art skills was conducted twice - in March 2008, one week before the eight week training started, and in May 2008, one week after it had been completed. The subjects took part in the programme twice a week, 
for $60 \mathrm{~min}$. per lecture, the same intervention adopted by Duronjić and Válková (2010) to evaluate the motor skills development in children with autism. The measurement took place in a gym, on judo mats. The initial and final measurements of motor abilities and the evaluation of skills of different martial arts elements were implemented in one exercise unit. During all tests of skills (initial and final measurements) the execution of the elements was recorded using a video-camera. For each subject and for each of their test repetitions, the correct execution of the exercise and any errors were established based on the recordings. Skills evaluation criteria were defined, ranging from 0 (the worst execution) to 7 points (perfect execution of the test). The recordings were viewed several times and the analytical evaluation method was applied to determine the accuracy of execution and establish the sum total of the subject's points.

\section{Sample of variable}

The study was conducted using eight motor tests and nine valid and reliable tests of martial arts skills, with associated descriptions of the essential characteristics, developed by a special team of martial arts experts (judo, karate, boxing and fencing) and population of people with ID at the Faculty of Sport in Ljubljana. All adopted tests are described in detail in Masleša's test battery (Masleša et al., 2009).

For measuring speed we adapted the 25 metre dash (Skorwonski, Horvat, Nocera, Roswal, \& Croce, 2009), the flexibility was measured with Pistotnik's tests (Pistotnik, 1991), for measuring the explosive leg strength was used the long jump, for arm strength we adapted the medicine ball push and for abdominal strength the adapted sit-ups test was used from the Eurofit Special the European fitness battery score variation among individuals with ID (Skorwonski et al., 2009). The agility was measured with Metikošu's tests, adapted for the population of Gan (inclusive) judo (Metikoš, Hofma, Prot, Pintar, \& Oreb, 1989).

\section{Motor tests}

1. FLEX - trunk flexibility test - touch-toe on a bench (cm).

2. SFLEX - shoulder girdle flexibility test - dislocation - flexion using a stick (cm).

3. LAG - test of agility while lying - crawling in a supine position $4 \mathrm{~m}$ forward, turning on the back and crawling in a prone position $4 \mathrm{~m}$ backwards (s).

4. SAG - test of agility while standing: execution of slide steps sideways for $4 \mathrm{~m}$, twice in both directions (s).

5. LJ - test of lower extremities' explosive power standing broad jump (cm).

6. ARME - test of arm and shoulder girdle endurance pushing of a large double-headed rubber ball (gym roll) with arms bent on chest to arms extended forwards (no. of repetitions).

7. SIT - trunk endurance test - sit-ups for $20 \mathrm{~s}$ (no. of repetitions).

8. DASH - speed test $-4 \times 4 \mathrm{~m}$ dash (s).

\section{Sample of tests for evaluation of selected martial arts skills Karate}

1. CT - straight punch - choku tsuki (3 times left, 3 times right).

2. AU - rising block - age uke ( 3 times left, 3 times right).

3. MG - front kick - mae geri ( 3 times left, 3 times right).

\section{Boxing}

1. ESK - movement of the body to avoid being hit esquive ( 3 times left, 3 times right).

2. DRK - combination of a left jab and a right hook (the combination is executed 3 times).

\section{Fencing}

1. FL - lunge (10 times).

2. FM - moving en garde ( 4 times for $6 \mathrm{~m}$ ).

Judo

1. FAL - combined execution of a backward fall ushiro ukemi and a sideward fall - yoko ukemi.

2. UGKG - combination of a floating-hip throw - uki goshi and a mat hold - kesa gatame.

\section{Ethical proof}

The judo club atmosphere is typical, with warm relations between staff, participants and parents. Staff and parents are open to new information as well as accepting new approaches. The staff informed the parents about the measurements and the purpose of the program. The authors had a short meeting with the staff and parents, where parents were asked to sign a consent letter. The research was also confirmed by a special Ethical committee at the Faculty of Sport in Ljubljana.

\section{Evaluation of martial arts skills}

During both testing sessions, the tests of skills performed by all study subjects were recorded with a video-camera. Therefore, the subjects' skill was evaluated following a series of viewings of the recordings. The evaluation method was analytical to guarantee a higher level of objectivity and impartiality (Majerič, 2004). The evaluation was based on detailed Masleša's checklists for measuring the martial arts skills, where the points were ascribed analytically, which means that different phases or parts of the movement were evaluated separately (Masleša et al., 2009). Using an eightgrade scale (grades ranging from 0-7 points), which included descriptions of essential characteristics of correct execution of the elements, one point was awarded to whichever of the seven characteristics of the element 
was executed correctly. Motor skills were evaluated on the basis of the sum total of points which the subject scored in each test of martial arts, with a higher number of points corresponding to a higher score. The evaluation was made by the observer working at the Faculty of Sport in Ljubljana. He was a specialist of martial arts and people with ID. The observer was given all the information about the peculiarities and limitations of the single participant in the study. Similar (qualitative) approach to the evaluation of motor skills was found in academic papers studying motor learning in the average population (Marjerič, 2004; Štihec, 1991; Božanić \& Bešlija, 2010), while for subjects with ID, the only accessible information was about motor skill learning from the point of view of precision and accuracy of throwing tasks (Yang \& Porretta, 1999; Matsuoka et al., 2011) and gripping forces (Latash, 2007).

\section{The training program}

During the training program participants were given the combination of feed forward and feedback mode, which is the most efficient movement control method when learning motor skills (Petrynski, 2010). Every single motor task was demonstrated and explained verbally before the execution. We followed the suggestions of Rice and Hernandez (2006) that feedback should be given just after a few trials and not too frequently, because it could interfere with learning and retention of motor skills in individuals with ID. The attention was focused on the results of the movement instead of performance itself.

The participants implemented Masleša's training program in which the training session was divided in three parts; (1) warm up, (2) central part, where participants evaluated the martial arts skills, (3) strength and cool down (Masleša et al., 2009).

Part (1) was composed by (a) games that lasted approximately 5 minutes, (b) two series of 25 seconds stretching in the seat and reach position and the shoulder stretch with a judo band, (c) two repetitions of crawling in a supine position ( $2 \mathrm{~m}$ slowly and $4 \mathrm{~m}$ as fast as possible) forward, turning on the back and crawling in a prone position ( $2 \mathrm{~m}$ slowly and $4 \mathrm{~m}$ as fast as possible) backwards, (d) slide steps sideways for $2 \mathrm{~m}$ slowly and $4 \mathrm{~m}$ as fast as possible, twice in both directions.

In the part (2) the participants had to perform four times each martial skill test. After each performed test (not after each repetition), they were given the feedback.

Part (3) was composed by (a) sprints four times $5 \mathrm{~m}$, on the judo mats, (b) two times $6 \mathrm{~m}$ of standing broad jumps forward, (c) three time 10 repetitions of push ups, (d) one minute of passing a medicine ball with arms bent on chest to arms extended forwards in pairs, (e) two series of 25 seconds stretching in the seat and reach position and the shoulder stretch with the judo band, (f) one minute of laying on the back with closed eyes.

\section{Data-processing methods}

The data were processed with the SPSS 17.0 statistical package, using descriptive statistics methods, whereas the differences between the initial and final measurements of motor abilities and motor skills were established with a t-test for dependent samples at a 5\% risk level. The reliability of motor skill tests was established with the Cronbach alpha test. The relationship between the results of selected motor ability tests and the average overall score in martial art skills was established with the Pearson's correlation coefficient. Additionally we calculated the correlation coefficient squared (known as the coefficient of determination, $\mathrm{R}^{2}$ ) that is a measure of the amount of variability in one variable (in our case the overall average score in martial art tests) that is explained by the other (every individual score in the complex of our motor ability tests). Partial coefficient was used to establish the correlation between the results of speed test (DASH) with the results of agility tests (LAG and SAG).

\section{RESULTS}

TABLE 1 shows that statistically significant differences were observed in the results of seven of eight motor ability tests. Our findings are similar to those reported in Davis, Zhang, and Hodson (2011), where a statistically significant difference was obtained after eight week physical activity program.

The participants of the study improved their results in both flexibility tests, FLEX - trunk flexibility test and FLEXS - shoulder girdle flexibility test. The differences were statistically significant $(p<0.05)$. The changes in flexibility could be due to adjustments at a neural level and because of more efficient (co)activation patterns between agonist-antagonist during the tests (Latash, 2007). It should be also emphasized that in the past participants didn't perform any flexibility training.

The participants also improved their results from the initial measurements in endurance testes SIT - trunk endurance test, ARME - test of arm and shoulder girdle endurance and LJ - test of lower extremities' explosive power. The findings of the study agree with others studies showing that subjects with ID improved their muscle strength and endurance after participating in a training program (Tsimaras \& Fotiadou, 2004; Davids, Zhang, \& Hodson, 2011). Participants also improved the results in DASH - speed test and SAG - test of agility while standing. All the differences between the initial and final measurement were also statistically significant $(\mathrm{p}<0.05)$. The least progress was established 
in the LAG test - agility while lying, probably because they were already familiar with a similar version of the test and had been executing it for a longer period of time. This influenced the results of the initial measurement and slowed down progress. Smaller improvement could be also reasoned by the lack of motivation while performing the final measurement in one participant, which was already reported in other academic papers (Wuang, Wang, Huang, \& Su, 2008).

Based on the results of the tests of specific martial arts skills, as shown in TABLE 2, the subjects improved their results in the final measurement in results of all tests of motor abilities. Statistical difference was established in eight of the nine tests. The results agree with the findings of Almeide, Corcos and Latas (1994) that people with ID can make important improvements during an extended learning process. Slightly poorer progress was observed in the UGKG test (combination of floating hip throw - uki goshi and mat hold - kesa gatame).

The absolute strongest progress was seen in the rising block test (AU), as the score (assigned points) in the initial measurement rose from 2.13 to 4.26 , with the standard deviation of 1.46 in the initial and 1.94 in the final measurement, followed by the tests of straight punch (CT), from 2.30 to $3.91(\mathrm{SD}=1.49$ and 1.56, respectively), fencing lunge (FL), from 2.83 to 4.35 $(\mathrm{SD}=1.44$ and 1.85 , respectively), and the en garde movement (FM), from 2.65 to 4.17 (SD = 1.37 and 1.61, respectively).

The least but still important progress was observed in both judo tests: combined execution of judo backward fall and judo sideways fall (FAL), as the score (assigned points) of initial measurement rose from 5.04 to 5.96 with the SD of 1.77 in the initial and 1.33 in the final measurement, and combination of floating-hip throw uki goshi and mat hold - kesa gatame (UGKG) with the mean values of 5.65 and 6.16 and $(\mathrm{SD}=1.58$ and 1.18 , respectively). The results show that there is still a considerable range of improvement even in skills that have been practiced for a long period of time. In those two judo tests the participants demonstrated the highest levels of skills in initial measurement, what is probably because of a bigger familiarity with the judo skills (Masleša et al., 2009).

The participants encountered the most difficulties and obtained lower scores during the initial measurement in the three asymmetric bimanual motor tasks (AU) rising block ( $\mathrm{M}=2.13$ points), (CT) straight punch $(\mathrm{M}=2.30$ points) and (DRK) combination of a left jab and a right hook with the mean value of 2.43 points, which is why their average scores were lower. Bilateral asymmetric tasks (AU, CT and DRK) are clearly more difficult to perform than symmetric tasks or tasks performed just with one hand, especially the first time you try them (Magill, 2011). Vuijk, Hartman, Scherder in Visscher (2010) found out that $70.9 \%$ of people with

TABLE 1

Comparison of the initial and final measurement in terms of motor test results

\begin{tabular}{|c|c|c|c|c|c|c|c|}
\hline Motor abilities & & M & SD & SE & $\mathbf{T}$ & Df & $\mathbf{p}$ \\
\hline FLEX & $\begin{array}{l}\mathrm{I} \\
\mathrm{F}\end{array}$ & $\begin{array}{l}32.04 \\
34.87\end{array}$ & $\begin{array}{l}9.91 \\
9.93\end{array}$ & $\begin{array}{l}2.07 \\
2.07\end{array}$ & -2.387 & 22 & .026 \\
\hline FLEXS & $\begin{array}{l}\mathrm{I} \\
\mathrm{F}\end{array}$ & $\begin{array}{l}101.00 \\
89.30\end{array}$ & $\begin{array}{l}21.16 \\
27.26\end{array}$ & $\begin{array}{l}4.41 \\
5.68\end{array}$ & 3.499 & 22 & .002 \\
\hline SIT & $\begin{array}{l}\mathrm{I} \\
\mathrm{F}\end{array}$ & $\begin{array}{l}10.13 \\
12.43\end{array}$ & $\begin{array}{l}2.56 \\
3.44\end{array}$ & $\begin{array}{l}0.53 \\
0.72\end{array}$ & -3.732 & 22 & .001 \\
\hline ARME & $\begin{array}{l}\mathrm{I} \\
\mathrm{F}\end{array}$ & $\begin{array}{l}24.96 \\
40.96 \\
\end{array}$ & $\begin{array}{l}12.43 \\
19.32 \\
\end{array}$ & $\begin{array}{l}2.59 \\
4.03\end{array}$ & -5.501 & 22 & .000 \\
\hline LJ & $\begin{array}{l}\mathrm{I} \\
\mathrm{F}\end{array}$ & $\begin{array}{l}156.30 \\
165.83\end{array}$ & $\begin{array}{l}35.76 \\
34.13\end{array}$ & $\begin{array}{l}7.46 \\
7.12\end{array}$ & -5.494 & 22 & .000 \\
\hline DASH & $\begin{array}{l}\mathrm{I} \\
\mathrm{F}\end{array}$ & $\begin{array}{l}10.57 \\
8.97\end{array}$ & $\begin{array}{l}3.99 \\
2.72\end{array}$ & $\begin{array}{l}0.83 \\
0.57\end{array}$ & 4.003 & 22 & .001 \\
\hline SAG & $\begin{array}{l}\text { I } \\
\text { F }\end{array}$ & $\begin{array}{l}12.67 \\
11.16 \\
\end{array}$ & $\begin{array}{l}4.95 \\
3.56\end{array}$ & $\begin{array}{l}1.03 \\
0.74\end{array}$ & 2.369 & 22 & .015 \\
\hline LAG & $\begin{array}{l}\text { I } \\
\text { F }\end{array}$ & $\begin{array}{l}18.45 \\
17.36\end{array}$ & $\begin{array}{l}11.63 \\
13.03\end{array}$ & $\begin{array}{l}2.42 \\
2.72\end{array}$ & 1.142 & 22 & .266 \\
\hline
\end{tabular}

Legend: M - mean value, SD - standard deviation, SE - standard error, T - t-value, P - statistical significance, Df - degrees of freedom, I - initial measurement, F - final measurement, FLEX - trunk flexibility test touch, SFLEX - shoulder girdle flexibility test, LAG - test of agility while lying, SAG - test of agility while standing, LJ - test of lower extremities' explosive power, ARME - test of arm and shoulder girdle endurance, SIT - trunk endurance test, DASH - speed test 
TABLE 2

Comparison of the results of the initial and final evaluation of martial arts skill tests

\begin{tabular}{|c|c|c|c|c|c|c|}
\hline Motor skills & & $\mathbf{M}$ & SD & SE & $T$ & p \\
\hline \multirow[t]{2}{*}{ CT } & I & 2.30 & 1.49 & 0.31 & \multirow{2}{*}{-6.450} & \multirow{2}{*}{.000} \\
\hline & $\mathrm{F}$ & 3.91 & 1.56 & 0.33 & & \\
\hline \multirow[t]{2}{*}{$\mathbf{A U}$} & I & 2.13 & 1.46 & 0.30 & \multirow{2}{*}{-6.057} & \multirow{2}{*}{.000} \\
\hline & $\mathrm{F}$ & 4.26 & 1.94 & 0.40 & & \\
\hline \multirow[t]{2}{*}{ MG } & I & 2.74 & 1.57 & 0.33 & \multirow{2}{*}{-4.970} & \multirow{2}{*}{.000} \\
\hline & $\mathrm{F}$ & 4.09 & 1.62 & 0.34 & & \\
\hline \multirow[t]{2}{*}{ DRK } & I & 2.43 & 1.24 & 0.26 & \multirow{2}{*}{-5.601} & \multirow{2}{*}{.000} \\
\hline & $\mathrm{F}$ & 3.57 & 1.41 & 0.29 & & \\
\hline \multirow[t]{2}{*}{ ESK } & I & 2.91 & 1.24 & 0.26 & \multirow{2}{*}{-4.491} & \multirow{2}{*}{.000} \\
\hline & $\mathrm{F}$ & 4.35 & 1.99 & 0.42 & & \\
\hline \multirow[t]{2}{*}{ FAL } & I & 5.04 & 1.77 & 0.37 & \multirow{2}{*}{-3.431} & \multirow{2}{*}{.002} \\
\hline & $\mathrm{F}$ & 5.96 & 1.33 & 0.28 & & \\
\hline \multirow[t]{2}{*}{ UGKS } & I & 5.65 & 1.58 & 0.33 & \multirow{2}{*}{-2.043} & \multirow{2}{*}{.053} \\
\hline & $\mathrm{F}$ & 6.16 & 1.18 & 0.25 & & \\
\hline \multirow[t]{2}{*}{ FL } & I & 2.83 & 1.44 & 0.30 & \multirow{2}{*}{-6.076} & \multirow{2}{*}{.000} \\
\hline & $\mathrm{F}$ & 4.35 & 1.85 & 0.39 & & \\
\hline \multirow[t]{2}{*}{ FM } & I & 2.65 & 1.37 & 0.29 & \multirow{2}{*}{-7.342} & \multirow{2}{*}{.000} \\
\hline & $\mathrm{F}$ & 4.17 & 1.61 & 0.34 & & \\
\hline
\end{tabular}

Legend: $\mathrm{N}$ - number of participants, $\mathrm{M}$ - mean value, SD - standard deviation, SE - standard error, $\mathrm{T}$ - t-value, $\mathrm{p}$ - statistical significance, I - initial measurement, F - final measurement, CT - straight punch - choku tsuki, AU - rising block - age uke, MG - front kick - mae geri, ESK - esquivague, DRK- combination of a left jab and a right hook, FL - lunge, FM - moving en garde, FAL - combined execution of a backward fall and a sideward fall, UGKG - combination of a floating- hip throw and a mat hold

mild ID demonstrated a relative weakness in the area of manual dexterity, while Wuang et al. (2008) suggested that this is presumably caused by the fact that fine and complex motors skills exert a greater demand on the maturity and integrity of the cortical nervous system.

In the TABLE 3 the results of Pearson's correlation coefficient are presented. Reliability of the average score of nine motor skill tests was determinate with the Cronbach alpha test $(\mathrm{I}=.902 ; \mathrm{F}=.922)$.

The results in TABLE 3 show a statistical significant correlation between the average overall score of nine tests of martial art skills with all results of motor ability used in our study expect one - flexibility of the shoulder girdle (FLEXS) in the initial measurement, while in the final measurement the statistical significant correlation was established with five tests of motor abilities (FLEX, LJ, DASH, LAG and SAG).

The results of TABLE 3 show that when participants achieved higher scores in the average overall score of motor skills, they achieved higher scores in the measurements of body flexibility (FLEX), trunk and arm and shoulder endurance (SIT and ARME) and the test of explosive power of lower extremities (LJ), while negative correlation was established with the scores of flexibility of the shoulder girdle (FLEXS), the score of speed (DASH) and both tests of agility (LAG and SAG). It should be emphasized that lower scores in the agility and speed tests represent a better result.

Majerič (2006), testing the motor skills of children at the physical education in the elementary schools established the correlation between the overall average score of selected motor skills from gymnastics, athletics, basketball and volleyball with a large number of motor ability tests expect one, the flexibility of the shoulder girdle test (FLEXS). The smallest variance could be explained and the lowest correlation between the overall average score in martial art skills was established with the same test also in our research. We could presuppose that performance of motor skills is not strongly affected by the ability of reaching extreme amplitudes of movements of the shoulder girdle. Opposite findings were established for the test of trunk flexibility (FLEX), where we could establish a statistically significant correlation with the overall average score of martial art skills in the initial measurement.

After the training program we could establish a higher correlation between the average overall score of martial art skills with the scores of four motor ability tests (FLEXS, DASH, AGG and AGS), while a smaller correlation if we compare it with the initial measurement was established as well with the scores of four motor ability tests (FLEX, SIT, ARME and LJ). 
The largest variance in the initial measurement could be explained in the test of explosive power of the legs LJ (37\%), while in the final measurement $51.2 \%$ of variance could be explained with the speed test - DASH, followed by the agility tests AGS (41\%) and AGG (39\%). The smallest variance could be explained in the test of arm and shoulder girdle endurance (ARME) in both measurements $(1.8 \%$ in the initial and $4.3 \%$ in the final measurement).

\section{TABLE 3}

Correlation between the results in the tests of selected motor abilities and the average score in nine tests of martial arts skills, in the initial and final measurements

\begin{tabular}{|l|c|c|c|c|c|}
\hline Motor abilities & & $\mathbf{N}$ & $\mathbf{R}$ & $\mathbf{R}^{2}$ & $\mathbf{p}$ \\
\hline FLEX & I & 23 & .476 & .226 & .011 \\
& F & 23 & .366 & .134 & .043 \\
\hline FLEXS & I & 23 & -.133 & .018 & .272 \\
& F & 23 & -.207 & .043 & 172 \\
\hline SIT & I & 23 & .440 & .194 & .036 \\
& F & 23 & .327 & .107 & .064 \\
\hline ARME & I & 23 & .344 & .118 & .018 \\
& F & 23 & .312 & .097 & 073 \\
\hline LJ & I & 23 & .608 & .370 & .001 \\
& F & 23 & .557 & .310 & .003 \\
\hline DASH & I & 23 & -.535 & .286 & .004 \\
& F & 23 & -.716 & .513 & .000 \\
\hline SAG & I & 23 & -.532 & .283 & .004 \\
& F & 23 & -.641 & .411 & .000 \\
\hline LAG & I & 23 & -.472 & .223 & .011 \\
& F & 23 & -.626 & .392 & .001 \\
\hline
\end{tabular}

Legend: $\mathrm{N}$ - number of participants, $\mathrm{R}$ - Pearson correlation coefficient, $\mathrm{R}^{2}$ - explained variance, I -initial measurement, $\mathrm{F}$ - final measurement, $\mathrm{p}$ - statistical significance, CT - straight punch choku tsuki, AU - rising block - age uke, MG - front kick - mae geri, ESK - esquivague, DRK - combination of a left jab and a right hook, FL - lunge, FM - moving en garde, FAL - combined execution of a backward fall and a sideward fall, UGKG combination of a floating- hip throw and a mat hold

\section{DISCUSSION}

A comparison between the initial and final measurements of the observed variables reveals that the study subjects who had consistently implemented the martial arts training programme improved all results in the investigated motor variables and skill tests. The training program, executed twice a week per 8 weeks (the same period was also adopted by Duronjić and Válková (2010) for preschool children with autism to improve motor skills), could be appropriate, also for the learning of complex, asymmetric bilateral motor skills in martial arts, but still needs experimental confirmation in future. Statistically significant differences were recorded in the results of seven motor ability tests and eight tests of martial art skills.

The improvement in the results of motor skills agree with the findings of Almeide, Corcos, and Latas (1994) that people with ID can make important improvements during an extended learning process. People with ID can achieve $100 \%$ progress, between performance in the initial and the final measurment, what happened in the rising block test (AU), while the range of improvement in the average population, after a few familiarization trials is only around 10\% (Jaric et al., 1993).

The participants encountered most difficulties and obtained lower scores during the initial measurements in the three asymmetric motor tasks, especially tests of manual dexterity, which agrees with some previous findings (Vuijk et al., 2010). Those tasks are clearly more difficult to perform than symmetric tasks or tasks performed just with one hand, especially the first time you try them (Magill, 2011).

With regards to the skill tests, the smallest differences between the initial and final measurements were observed in the judo tests, especially in the hip throw/mat hold test (UGKG), what is probably because of a bigger familiarity with the judo skills (Masleša et al., 2009). The findings of the study also show that people with ID are able to improve performance in a considerable way even in motor skills that have been practiced for a longer period of time.

It is assumed that one of the subjects, whose result in the final measurement of agility while lying (LAG) was much lower compared to the initial measurement, experienced a decrease in motivation during the execution of the test, which is a much more frequent situation among people with ID than in other populations (Eichstaedt \& Lavary, 1992; Masleša et al., 2009).

After the training program we could establish a higher correlation between the average overall score of martial art skills with the scores of four motor ability tests (FLEXS, DASH, AGG and AGS), while a smaller correlation if we compare it with the initial measurement was established as well with the scores of four motor ability tests (FLEX, SIT, ARME and LJ).

Almeida et al. (1994) found that people who improved their results in motor skills were also successful in achieving bigger accelerations and velocities of movements. Studies of the effects of practice movement speed suggest that slowness is unlikely to be related to an inability to produce sufficient muscle forces in people with Down syndrome, but rather reflects differences in neural commands (Latash, 2007). The development of primary, premotor and supplementary motor areas influ- 
ence the development of executive functioning (Ridler et al., 2006). Therefore, after the training program, participants could be more effective (needed shorter time) for planing and executing the motor tasks, what could be one of the reasons why the results in speed and agility test were better.

The partial correlation test also showed that results of the speed test (DASH) were in strong correlation with the test of agility while standing - SAG $(r=.955)$ and with the test of agility while lying - LAG $(r=.863)$, what could give support to the relationship with executive functioning. Similar, strong correlation between the results speed and agility tests were also established in testing intellectually average developed women (Vescovi \& McGuigan, 2008) and in professional soccer players (Little \& Williams, 2005).

After the training program the correlation between the test of explosive power ( $\mathrm{LJ}$ ) and the overall score of martial art skills decreased from $r=.608$ (what was also the strongest correlation in the initial measurement) to $\mathrm{r}=.557$. We can assume that during the training program some adjustments at the neural level and inter-muscular patterns occurred (Almeida el al., 1994; Latash, 2007) what interfered with the demand of strength and endurance that is needed for the performance of the selected motor skills. After the training program, martial arts skills could be performed in a more "relaxed" and fluent (natural) way.

The training of Gan judo is organised in (more or less) homogeneous groups. In this way motivation can be influenced, as in people with ID it is often another consequence of slower progress. Training in groups where the exercisers do not differ substantially is smoother and the coach is not required to interrupt the training process often, which was also established by Majerič (2004). It should also be noted that the norms for the population of people with ID who practice judo differ from those which apply to other populations. The training is not guided by only one coach, but rather several coaches are standing on the mats at the same time. In the Slovenian town Koper, there are five coaches supervising and leading the training of ten exercisers. In Ljubljana, two coaches guide six exercisers. This more individualised approach improves progress and increases safety during the training.

\section{CONCLUSION}

After the training process positive changes in motor abilities and motor skills of Gan judokas had been noted. To access the effects of the training program additional research in future is needed. Including different content in training programmes could be a valuable addition to the custom process, boosting the subjects' motivation.
Finally, it is worth reiterating that by improving motor abilities and expanding the boundaries of skills, people with ID enhance their quality of life. Further research is needed to specifically address many of the findings of this study from the points of view of psychology and special education so as to underpin the results and provide a broader context. There are plenty of research challenges ahead and this field will no doubt receive more research attention in the future and thus contribute to a higher quality of intellectual disabled people's engagement in sport as well as in life.

\section{REFERENCES}

Aleksandrović, M., Naumovski, A., Radovanović, D., Georgijev, G. \& Popovski, D. (2007). The influence of basic motor abilities and anthropometric measures on the specific motor skills of talented water polo players. Physical education and sport, 5(1), 65-74.

Almeida, G. L., Corcos, D. M., \& Latash, M. L. (1994). Practice and transfer effects durinf fast single joint elbow movements in individuals with Down syndrome. Physical teraphy, 74, 1000-1016.

Božanić, A., \& Bešlija, T. (2010). Relations between fundamental motor skills and specific karate technique in 57 year old begginers. Sport science, 3, 79-83.

Burnik, S., \& Brod, T. (2006). Judo za otroke in mladostnike $\mathrm{z}$ zmerno motnjo $\mathrm{v}$ duševnem razvoju [Judo for children and adolescents with moderate mental disability]. In R. Pišot (Ed.), 4th International Symposium: Child in Motion (p. 51). Koper: University of Primorska, Science and Research Centre.

Chen, D. D., Kaufman, D., \& Chung, M. (2001). Emergent patterns of feedback strategies in performing a closed motor skill. Perceptual and Motor Skills, 93, 197-204.

Choi, S., French, R., Meeuwsen, H. J., \& Stenwall, J. (1999). Learning and control of simple aiming movements by adults with profound mental retardation. Adapted Physical Activity Quarterly, 16, 167-177.

Dadić, T. (2000). Šport kot orodje socialnega dela in bogatitve življenja uporabnikov v obalnih delavnicah za delo pod posebnimi pogoji [Sport as an instrument in social work activities and as a valuable addition to the lives of participants in workshops for people with special needs in the Slovenian Littoral]. Graduation thesis, University of Ljubljana, Faculty of Social Work, Ljubljana.

Davis, K., Zhang, G., \& Hodson, P. (2011). Promoting health related fitness for elementary students with intellectual disability through a specifically designed activity program. Journal of policy \& practice in intellectual disabilities, 8(2), 77-84. 
Duronjić, M., \& Válková, H. (2010). The influence of early intervention movement programs on motor skills development in preschoolers with autist spectrum disordes (case study). Acta Universitatis Palackianae Olomucensis. Gymnica, 40(2), 37-45.

Eichstaedt, C., \& Lavary, B. (1992). Physical activity for individuals with mental retardation: Infancy through adulthood. Champaign, IL: Human Kinetics.

Filipčič, T. (2003). Antropometrične značilnosti in motorične sposobnosti učencev in učenk $\mathrm{z}$ lažjo motnjo $\mathrm{v}$ duševnem razvoju [Anthropometric characteristics and motor abilities of male and female pupils with mild mental disability]. Šport, 5l(2), 40-45.

Finn, K., \& Válková, H. (2007). Motor skill development in preschool children with mental and developmental disorders - the diference after a one year comprehensive education program. Acta Universitatis Palackianae Olomucensis. Gymnica, 37(4), 91-98.

Fragala-Pinkham, M. A., Haley, S. M., Rabin, J., \& Kharasch, V. S. (2005). A fitness program for children with disabilities. Physical therapy, 85(11), 1182-1200.

Francis, R., \& Rarick, G. (1960). Motor characteristics of the mentally retarded [Cooperative research monograph no. 1]. Washington, DC: U. S. Department of Health, Education and Welfare.

Frey, G. C., \& Chow, B. (2006). Relationship between BMI, physical fitness, and motor skills in youth with mild intellectual disabilities. International Journal of Obesity, 30, 861-867.

Gleser, J., Margulies, J., Nyska, M., Porat, S., Mendelberg, H., \& Wertman, E. (1992). Physical and psychosocial benefits of modified judo practice for blind, mentally retarded children: A pilot study. Perceptual and Motor Skills, 74, 915-925.

Goffman, E. (1991). Stigma. Ljubljana: Časopis za kritiko znanosti.

Hadžikadunić, A., Hadžikadunić, M., Pavlović, P., \& Jakšić, D. (2009). The relationship between basic motor and functional abilities of students with their results in some basketball tests. In S. Simović (Ed.), Međunarodni naučni kongres „Antropološki koncepti sporta, fizičkog vaspitanja i rekreacije“(pp. 171-177). Banja Luka: University of Banja Luka.

Haubenstricker, J., \& Seefeldt, V. (1986). Acquisition of motor skills during childhood. In V. Seefeldt (Ed.), Physical activity and well being (pp. 42-102). Reston, VA: AAHPERD.

Hayes, B. K., \& Taplin, J. E. (1993). Development of conceptual knowledge in children with mental retardation. American Journal on Mental Retardation, 98, 293-303.

Jaric, S., Corcos, D. M., Agarwal, G. C., \& Gottlieb, G. L. (1993). Principles for learning single joint movements: II. generalizing a learning behaviour. Experimental brain research, $94,514-521$.
Jovanović, B., Bala, G., Banić, M. et al. (1983). Motorične sposobnosti lakše psihički ometanih učenika [Motor abilities of pupils with mild mental disability]. Defektol, 19, 39-46.

Karpljuk, D. (1999). Učinek eksperimentalnega programa vadbe na razvoj vzdržljivosti pri učenkah in učencih $v$ zgodnjem pubertetnem obdobju [Impact of an experimental training programme on the development of endurance of male and female pupils in early adolescence]. Doctoral dissertation, University of Ljubljana, Faculty of Sport, Ljubljana.

Latash, M. L. (2007). Learning motor synergies by persons with Down syndrome. Journal of intellectual disability research, 51(12), 962-971.

Latash, M. L., \& Corcos, D. M. (1991). Kinematic and electromyographic characteristics of single joint movements of individuals with Down syndrome. American journal of mental retardation, 96, 198-201.

Little, T., \& Williams, A. G. (2005). Specificity of acceleration, maximum speed, and agility in professional soccer players. Journal of strength and conditioning research, 19(1), 76-78.

Magill, R. A. (2011). Motor learning and control: Concepts and applications (9th ed.). Boston: McGrawHill.

Majerič, M. (2004). Analiza modelov ocenjevanja športnih znanj pri športni vzgoji [Analysis of models for assessing sport skills in physical education]. Doctoral dissertation, University of Ljubljana, Faculty of Sport, Ljubljana.

Masleša, S., Videmšek, M., \& Karpljuk, D. (2008). Comparison of mentally challenged people's knowledge of selected elements of martial arts before and after five weeks of training. In G. Starc, M. Majerič, \& K. Bizjak (Eds.), The Heart of Europe: 4th International Symposium Youth Sport (pp. 75-76). Ljubljana: Faculty of Sport.

Masleša, S., Videmšek, M., \& Karpljuk, D. (2009). Analiza izbranih morfoloških značilnosti, gibalnih sposobnosti in praktičnih znanj borilnih športov po osemtedenskem procesu vadbe pri osebah z motnjo $\mathrm{v}$ duševnem razvoju [Analysis of mentally challenged people's selected morphological characteristics, motor abilities and practical knowledge of martial arts]. Šport, 57(1/2), 93-96.

Matsouka, O., Trigonis, J., Simakis, S, Chavenetidis, K., \& Kioumomourjoglou, E. (2010). Variability of practice and enhancement of acquisation, retention and transfer of learning using an outdoor throwing motor skill by children with intellectual disabilities. Studies in Physical Culture \& Tourism, 17(2), 157-164.

Metikoš, D., Hofma, E., Prot, F., Pintar, G., \& Oreb, Ž. (1989). Mjerjenje bazičnih motoričkih dimenzija sportaša. Zagreb: Fakultet za fizičku kulturu. 
Ninot, G., Bilard, J., \& Delignières, D. (2005). Effects of integrated or segregated sport participation on the physical self for adolescents with intellectual disabilities. Journal of Intellectual Disability Research, 49(9), 682-689.

Oriel, K. N., George, C. L., \& Blatt, P. J. (2008). The impact of community based exercise program in children and adolescents with disabilities: A pilot study. Physical disabilities: education and related services, 27, 5-20.

Petrynski, W. (2007). Bernstein's construction of movement model and contemporary motor control and motor learning teories. Human Kinetics, 8(2), 136-146.

Pistotnik, B. (1991). Ovrednotenje različnih merskih postopkov gibljivosti. Doctoral disertation, University of Ljubljana, Faculty of Sport, Ljubljana.

Rarick, G., \& Dobbins, D. (1972). Basic components in the motor performance of educable mentally retarded children: Implications for curriculum development [Final report, project no. 142714]. Washington, DC: U. S. Department of Health, Education, and Welfare.

Ridler, K., Veijola, J. M., Tanskanen, P., Miettunen, J., Chitnis, X., Suckling, J. et al. (2006). Fronto-cerebellar systems are associated with infant motor and adult executive functions in healthy adults but not in schizophrenia. Proceedings of the National Academy of Sciences of the United States of America, 103, 15651-15656.

Rice, M. S., \& Hernandez, H. G. (2006). Frequency of knowledge of results and motor learning in persons with developmental delay. Occupational theraphy international, 13(1), 35-48.

Schmidt, R. A., \& Lee, T. D. (1999). Motor control and learning: A behavioral emphasis (3rd ed.). Champaign, IL: Human Kinetics.

Skowronski, V., Horvat, M., Nocera, J., Roswal, G., \& Croce, R. (2009). Eurofit special: European fitness battery score variation among individuals with intellectual disabilities. Adapted Physical Activity Quarterly, 26, 54-67.

Stanish, H. I., Temple, V. A., \& Frey, G. C. (2006). Health-promoting physical activity of adults with mental retardation. Mental retardation and development disabilities, 12, 13-21.

Štihec, A. (1991). Analiza eksperimentalnega programa vadbe s poudarkom na osvajanju specifičnih športnih znanj [Analysis of experimental training program with an emphasis on mastering specific sport skills]. Doctoral dissertation, University of Ljubljana, Faculty of Sport, Ljubljana.

Temple, V., Frey, G. C., \& Stanish, H. I. (2006). Physical activity of adults with mental retardation: Review and research needs. American Journal of Health Promotion, 2l(1), 2-12.
Tsimaras, V. K., \& Fotiadou, E. G. (2009). Effect of training on the muscle strength and dynamic balance ability of adults with Down syndrome. Journal of Strength and conditioning research, 18(2), 343-247.

Yamaki, K. (2005). Body weight status among adults with intellectual disability in the community. Ment. retard, 43, 1-10.

Yang, J. J., \& Poretta, J. J. (1999). Sport/leisure skill learning by adolescents with mild mental retardation: A four step strategy. Adapted Physical Activity Quarterly, 16, 300-315.

Yun, J., \& Shapiro, D. R. (2004). A quantitative approach to movement skill assessment for children with mental retardation. Adapted Physical Activity Quarterly, 21, 269-280.

Vescovi, J. D., \& McGuigan, M. R. (2008). Relationship between sprinting, agility and long jump ability in female athletes. Journal of sport science, 26(1), 97-107.

Vuijk, P. J., Hartman, E., Scheder, E., \& Visscher, C. (2010). Motor performance of children with mild intellectual disability and borderline intellectual functioning. Journal of intellectual disability reseach, 54(11), 955-965.

Wuang, Y. P., Wang, C. C., Huang, M. H., \& Su, C. Y. (2009). Profiles of cognitive predictors of motor functions among early school age children with mild intellectual disabilities. Journal of intellectual disability research, 52(12), 1048-1060.

Wulf, G., Shea, C., \& Lewthwaite, R. (2010). Motor skill learning and performance: a rewiev of influential factors. Medical education, 44(1), 75-84.

Zhang, J. (2005). A quantitative analysis of motor development delays by adolescents with mild mental retardation. Palestra Winter, 21(1), 7-8.

\section{MOTORICKÉ SCHOPNOSTI, POHYBOVÉ DOVEDNOSTI A VZTAH MEZI NIMI U OSOB S MENTÁLNÍM POSTIŽENÍM PŘED OSMITÝDENNIIM KURZEM BOJOVÝCH UMĚNÍ A PO JEHO UKONČENÍ}

(Souhrn anglického textu)

VÝCHODISKA: Je známo, že část populace osob s mentálním postižením má sklon k obezitě a horšímu zdravotnímu stavu. Proto by v jejich životech měl hrát významnou roli sport. Navrhnout vědecky a profesionálně účinné tréninkové programy pro sportovní vyžití osob s mentálním postižením, sestávající z nezbytné metodiky a didaktických pokynů, je sice těžký úkol, ale stává se nezbytností pro blízkou budoucnost.

CÍL: Cílem studie je stanovit vzájemný vztah mezi vybranými motorickými schopnostmi a pohybovými dovednostmi v rámci bojových umění, jakož i to, jak a do jaké míry osoby s mentálním postižením (MP), které 
pravidelně trénují judo, mohou po osmitýdenním tréninkovém kurzu ve svých dovednostech v oblasti bojových umění (judo, karate, box a šerm) dosáhnout zlepšení. Zajímalo nás také, zda došlo k jakýmkoli změnám ve vybraných motorických dovednostech.

METODY: Měření motorických schopností a dovedností $\mathrm{v}$ oblasti vybraných bojových umění bylo provedeno dvakrát - v březnu 2008, týden před začátkem kurzu, a v květnu 2008, týden po jeho ukončení. Tréninkový kurz trval dva měsíce v rozsahu dvou lekcí týdně. Zkoumaný vzorek sestával z 5 žen a 18 mužů ve věku mezi 16 a 36 lety s mírným až středně těžkým mentálním postižením. Studie byla provedena pomocí 8 testů pro hodnocení motorických schopností a 9 testů pro hodnocení dovedností v oblasti bojových umění.

VÝSLEDKY: Výsledky t-testu pro závislé vzorky prokázaly statisticky významné rozdíly mezi úvodními a konečnými naměřenými hodnotami $\mathrm{v}$ sedmi testech motorických schopností a osmi testech dovedností v oblasti bojových umění, zatímco významná souvztažnost byla zjištěna mezi celkovým průměrným skóre u bojových umění a výsledky sedmi testů motorických schopností $\mathrm{v}$ úvodních a pěti v konečných naměřených hodnotách.

ZÁVĚRY: Po ukončení kurzu byly u svěřenců zaznamenány pozitivní změny $\mathrm{v}$ motorických schopnostech a pohybových dovednostech. Účinky tréninkového programu by měly být potvrzeny budoucími studiemi. Podobným zlepšováním motorických schopností a rozšiřováním hranic dovedností mohou osoby s mentálním postižením zlepšit kvalitu svého života. Pokud bude této činnosti v budoucnu věnována pozornost, může toto vést ke zlepšení kvality zapojení osob s mentálním postižením do sportovních činností, ale i zlepšení jejich života obecně.

Klíčová slova: motorická výchova, retence, souvztažnost.

\section{prof. Samo Masleša}

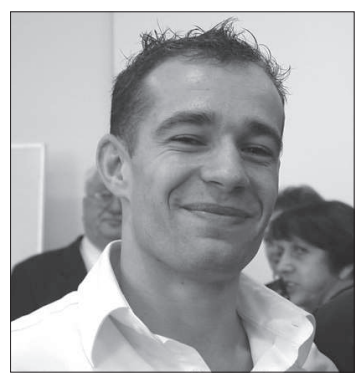

Kvedrova 4

6000 Koper

Slovenia

\section{Education and previous work experience}

2001-2006 - University in Ljubljana, Faculty of Sport adapted physical education.

2006-2012 - Ph.D. study (waiting for the defense of the doctoral thesis in the beginning of 2013) at University of Ljubljana, Faculty of Sport.

2006-2008 - Asist. at Faculty of Sport, University of Ljubljana.

2010-2011 - President of trainers commision at Slovenian Judo Federation.

\section{First-line publications}

Masleša, S., Videmšek, M., \& Karpljuk, D. (2009). Analiza izbranih morfoloških značilnosti, gibalnih sposobnosti in praktičnih znanj borilnih športov po osemtedenskem procesu vadbe pri osebah z motnjo $\mathrm{v}$ duševnem razvoju [Analysis of mentally challenged people's selected morphological characteristics, motor abilities and practical knowledge of martial arts]. Šport, 57(1/2), 93-96.

Masleša, S., \& Karpljuk, D. (2008). Proces dehidracije in rehidracije pri judu [Dehydration and rehydration processes in judo]. Šport, 56(3/4), 57-60. 